\title{
ANALISIS NERACA PASOKAN DAN KEBUTUHAN SAPI DAN DAGING SAPI DI JAWA BARAT
}

\section{ANALYSIS OF BALANCE SUPPLY AND DEMAND OF CATTLE AND BEEF CATTLE IN WEST JAVA}

\author{
Achmad Firman*, Mumun M Sulaeman, Linda Herlina, Marina Sulistyati \\ Departemen Sosial dan Ekonomi Pembangunan Peternakan \\ Fakultas Peternakan, Universitas Padjadjaran \\ Jl. Raya Bandung Sumedang Km 21, Jatinangor Sumedang \\ *Email: ahmadpedum@yahoo.com \\ (Diterima 11-04-2018; Disetujui 25-04-2018)
}

\begin{abstract}
ABSTRAK
Komoditas sapi dan daging sapi telah menjadi komoditas politik karena kenaikan harga daging sapi telah direspon secara signifikan oleh lembaga legislatif maupun eksekutif. Jawa Barat menjadi salah satu provinsi yang dikategorikan sebagai wilayah konsumsi daging sapi karena kebutuhan sapi dan daging sapi tidak mampu dipasok oleh sapi-sapi lokal di Jawa Barat. Kekurangan daging sapi dipasok dari luar provinsi ataupun dari luar negeri. Penelitian ini bertujuan untuk melihat jumlah produksi sapi dan daging sapi ke Jawa Barat, jumlah kebutuhan sapi dan daging sapi di Jawa Barat, serta keseimbangan antara pasokan dan kebutuhan sapi dan daging sapi di Jawa Barat. Penelitian ini menggunakan metode kuantitatif dengan data sekunder sebagai basis analisisnya. Hasil penelitian menunjukkan bahwa jumlah produksi sapi yang dihitung dari jumlah populasi sapi, produksi pedet, dan jumlah pemasukan sapi yang berasal dari luar provinsi ataupun luar negeri, dan stok sapi. Pada tahun 2015, jumlah populasi sapi Jawa Barat sebanyak 425.486 ekor sapi, 60.990 ekor pedet, dan 219.226 ekor sapi hasil pemasukan. Jumlah produksi daging sapi mampu mencapai $75,477,941 \mathrm{~kg}$. Total kebutuhan sapi dan daging sapi di Jawa Barat masing-masing sebanyak 408.881 ekor dan $84.733 .150 \mathrm{~kg}$. Berdasarkan data pasokan dan kebutuhan daging sapi dapat dihitung keseimbangan neraca daging sapi sapi di Jawa Barat. Neraca daging sapi di Jawa Barat mengalami defisit sepanjang tahun 2011-2015.
\end{abstract}

Kata Kunci: Produksi, Pasokan, Konsumsi, Neraca, Daging Sapi

\begin{abstract}
Cattle and beef commodities have become a political commodity because the increase in beef prices has been responded significantly by both legislative and executive institutions. West Java became one of the provinces categorized as the area of beef consumption because the needs of cattle and beef cannot be supplied by local cattle in West Java. Lack of beef cattle is supplied from outside the province or abroad. This study aims to see the amount of cattle and beef cattle production to West Java, the number of cattle and beef cattle needs in West Java, as well as the balance between supply and demand of beef and beef cattle in West Java. This research used quantitative method with secondary data as its base of analysis. The results showed that the number of cattle production calculated from the number of cattle population, the production of calf, and the amount of imported cattle from outside the province or abroad. In 2015, the number of West Java cattle population
\end{abstract}


amounted to 425,486 heads, 60,990 calves, and 219,226 heads of imported cattle. The amount of beef cattle production can reach 75,477,941 $\mathrm{kg}$. The total requirement of cattle and beef cattle in West Java was 408,881 heads and 84,733,150 kg. Based on data of supply and requirement of beef cattle could be calculated balance of cattle beef in West Java. The balance of beef cattle in West Java had a deficit meat during 2011-2015.

Keywords: Production, Supply, Consumption, Balance, Beef Cattle

\section{PENDAHULUAN}

Komoditas sapi potong telah menjadi komoditas politis karena kenaikan harga daging sapi langsung direspon oleh presiden dan lembaga legislatif. Kepanikan atas kenaikan daging sapi di pasaran tersebut telah menjadi fokus perhatian pemerintah. Pemerintah berusaha untuk menurunkan harga daging sapi dari Rp 120.000/kg menjadi Rp 80.000/kg pada tahun 2016 . Namun, sampai saat ini harga daging sapi tetap bertahan.

Fenomena bertahannya harga daging sapi tersebut karena ekses demand daging sapi masih cukup besar. Pemerintah telah melakukan dua kebijakan guna menurunkan harga daging sapi, yaitu operasi pasar dan impor daging kerbau dari India. Akan tetapi, kebijakan tersebut belum efektif untuk menurunkan harga daging sapi. Hal Ini dapat menjadi bukti bahwa ekses demand daging sapi di Indonesia masih cukup besar walaupun pemerintah melakukan berbagai kebijakan penurunan harga daging.
Beberapa wilayah yang dikategorikan wilayah konsumsi daging sapi adalah DKI Jakarta, Jawa Barat, dan Banten. Provinsi Jawa Barat menjadi salah satu wilayah konsumsi daging sapi karena kemampuan pasokan sapi lokal belum mampu memenuhi kebutuhan daging sapi yang cukup besar. Adanya kebijakan penurunan harga daging sapi oleh pemerintah merupakan respon positif bagi konsumen atau masyarakat golongan ekonomi lemah untuk dapat menikmati daging sapi. Namun, kebijakan pemerintah tersebut belum mampu sepenuhnya dirasakan oleh masyarakat ekonomi lemah karena harga daging sapi masih di atas seratus ribu.

Kategori Jawa Barat sebagai wilayah konsumsi dipacu oleh pusatpusat ekonomi yang terus berkembang, seperti Bandung Raya, Cirebon, Bogor, dan Depok. Di samping itu, terdapat beberapa wilayah yang dikenal sebagai sentra sapi potong di Jawa Barat, seperti Kabupaten Tasikmalaya, Majalengka, Sumedang, Subang, Indramayu, dan Ciamis. Kabupaten Tasikmalaya dikenal 
sebagai wilayah pembibitan sapi lokal sedangkan Kabupaten Bogor dikenal dengan pemasok sapi impor karena banyak perusahaan penggemukan sapi yang berada di wilayah ini.

Pemerintah Provinsi Jawa Barat melalui Dinas Ketahanan Pangan dan Peternakan telah berupaya untuk meningkatkan populasi sapi. Upayaupaya yang dilakukan meliputi penyelamatan betina produktif dari pemotongan, mendatangkan sapi indukan Peranakan Ongole dari Jawa Timur, pengembangan populasi sapi Pasundan yang telah menjadi sapi lokal asli Jawa Barat.

Orientasi peternakan sapi potong rakyat di Jawa Barat lebih cenderung untuk pembiayaan. Para peternak cenderung memelihara indukan dan dikawin suntik dengan semen dari jenis Simental ataupun Limosin. Para peternak menyukai sapi persilangan karena sapisapi turunan Simmental merupakan ternak unggul yang mampu menghasilkan daging yang baik dan berkualitas tinggi serta mempunyai nilai jual yang tinggi, populasinya telah cukup banyak bahkan telah mencapai turunan keempat (Syafrizal, 2011; Latifah et al, 2016). Di sisi lain, perusahaan penggemukan cenderung memelihara sapi potong bakalan dari Australia karena sifatnya yang cepat tumbuh dengan pertambahan bobot badan di atas $1 \mathrm{~kg}$ melalui pemberian pakan yang berkualitas (Firdaus et al, 2012). Para pelaku usaha sapi potong tersebut merupakan produsen sapi potong di Jawa Barat.

Sebenarnya, apa yang terjadi dengan sistem neraca pasokan dan kebutuhan daging sapi di Jawa Barat. Apakah wilayah Jawa Barat kekurangan pasokan sapi dan daging sapi untuk memenuhi konsumsi sapi dan daging sapi. Berapa besar konsumsi daging sapi di Jawa Barat. Identifikasi masalah tersebut menjadi dasar untuk penelitian ini.

\section{TINJAUAN PUSTAKA}

Terjadinya supply demand disebabkan adanya sumberdaya yang melimpah di suatu wilayah, di sisi lain adanya wilayah yang kekurangan sumberdaya, sehingga terjadi pasokan barang dan jasa dari wilayah surplus produksi ke wilayah yang kekurangan. Berdasarkan asumsi pasar persaingan sempurna, fungsi penawaran dibangun dari teori produksi melalui penurunan fungsi keuntungan perusahaan baik pada kasus satu output, beberapa input, maupun pada kasus beberapa output dan 
beberapa input atau diturunkan melalui fungsi biaya yakni bagian atas kurva marginal perusahaan setelah dipotong oleh biaya variabel rata-rata minimum (Koutsoyiannis, 1982). Selanjutnya, penentuan keputusan produksi tersebut dapat didasarkan atas dua pilihan, yaitu meminimumkan biaya produksi pada tingkat tertentu dan memaksimalkan keuntungan yang dapat diperoleh dengan menurunkan fungsi keuntungan. Pada kondisi tertentu, para produsen atau petani bisa melakukan revisi produksi berdasarkan dugaan mereka terhadap apa yang mereka anggap sebagai proporsi yang normal terhadap perbedaan yang terjadi dengan yang sebelumnya dianggap normal (Nerlove, 1958 dalam Hutahuruk, 1996).

Kebutuhan atau permintaan merupakan banyaknya kesatuan barang yang akan dibeli oleh pembeli pada bermacam-macam tingkat harga dalam jangka waktu tertentu dan syarat tertentu (Rusdi dan Suparta, 2010). Permintaan dapat dikatakan juga sebagai keinginan (desire) untuk mendapatkan barang dan jasa yang diikuti oleh kemampuan beli (purchasing power). Permintaan merupakan jumlah barang yang diminta oleh konsumen pada suatu pasar (Daniel, 2002). Sementara pasar adalah tempat terjadinya transaksi antara produsen dan konsumen atas barang-barang ekonomi. Fungsi permintaan seorang konsumen terhadap suatu barang merupakan fungsi dari harga barang itu sendiri, harga barang lain dan pendapatannya, di mana pendapatan adalah sebagai fungsi kendala dalam mencapai maksimalisasi utilitas (Koutsoyiannis, 1982).

Faktor-faktor yang mempengaruhi permintaan terhadap sesuatu barang antara lain (Sukirno, 2013): (1) Harga barang itu sendiri, (2) Harga barangbarang lain, (3) Pendapatan para pembeli, (4) Distribusi pendapatan, (5) Cita rasa masyarakat, (6) Jumlah penduduk, dan (7) Ekspektasi tentang masa depan. Setiap konsumen memiliki daya pilih atas produk yang akan dikonsumsi. Hal ini sangat tergantung pada harga barang utama tersebut yang akan dikonsumsi oleh konsumen. Apabila harga barang utama lebih tinggi, maka konsumen akan mengalihkannya kepada barang lainnya. Ada tiga jenis barang-barang lainnya yang apabila konsumen mengalihkan barang utama, yaitu barang pengganti, barang pelengkap, dan barang netral (Sukirno, 2013).

Daging sapi merupakan salah satu bahan pangan yang mengandung protein. Harga daging ini terus mengalami 
peningkatan harga dari tahun ke tahun. Sampai saat ini, harga daging sapi masih bertahan di atas seratus ribu per kilonya. Pemerintah melakukan penerapan kebijakan harga dasar untuk komoditas daging sapi pada nilai $\operatorname{Rp} 80.000 / \mathrm{kg}$ nya. Kebijakan ini diikuti dengan kebijakan lainnya dalam rangka mendukung penurunan harga daging sapi, yaitu operasi pasar dan impor daging kerbau dari India yang harganya sangat murah. Akan tetapi, kebijakan ini belum mampu menurunkan harga daging di bawah seratus ribu.

Atas dasar kebijakan di atas, pasokan dan kebutuhan sapi dan daging sapi di Jawa Barat dapat menjadi acuan bagi wilayah konsumen lainnya. Jumlah pasokan sapi yang berasal dari produksi sapi-sapi lokal, pemasukan sapi dari luar wilayah, dan pengeluaran/pemotongan sapi dari wilayah Jawa Barat dapat menentukan berapa banyak sapi yang diperlukan untuk konsumsi daging di Jawa Barat. Pemasukan sapi dari luar dapat menjadi penyangga bagi sapi-sapi lokal agar tidak tereksploitasi untuk dipotong besar-besaran.

\section{METODE PENELITIAN}

\section{Objek Penelitian}

Objek penelitian ini adalah datadata sekunder yang terkait dengan pasokan dan permintaan sapi dan daging sapi di Jawa Barat.

\section{Metode Penelitian}

Penelitian ini menggunakan metode kuantitatif dari data yang diperoleh. Adapun untuk menguraikan dari hasil analisis digunakan deskriptif untuk menguraikan hasil-hasil analisis dari data dan informasi yang diperoleh dalam bentuk hubungan, sebab akibat, dan sebagainya.

\section{Penentuan Lokasi Penelitian}

Lokasi penelitian ditentukan secara purposif karena Provinsi Jawa Barat merupakan provinsi penyangga ibu kota dan masuk dalam kategori wilayah konsumsi sapi dan daging sapi.

\section{Teknik Pengumpulan Data}

Data yang digunakan dalam penelitian ini adalah data sekunder. Data sekunder adalah data yang telah diolah lebih lanjut dan disajikan dengan baik oleh pihak pengumpul data primer atau pihak lain (Nindi, 2013). Data sekunder yang dikumpulkan berasal dari instansi terkait dengan penelitian, yaitu BPS dan Dinas Peternakan Provinsi Jawa Barat. 


\section{Operasional Variabel}

Operasional variabel adalah menguraikan istilah-istilah yang digunakan dalam penelitian ini, yaitu:

1. QSTs/ds adalah pasokan sapi atau daging sapi yang dihitung dalam satuan ekor/ton.

2. QPs/ds adalah populasi sapi atau produksi daging sapi eksisting pada tahun bersangkutan yang dihitung dalam satuan ekor/ton.

3. STs/ds adalah stok sapi atau stok daging sapi yang dihitung dari jumlah pasokan sapi tahun bersangkutan dikurangi dengan pengeluaran dan pemotongan sapi dihitung dengan satuan ekor/ton.

4. QMs/ds adalah pemasukan sapi atau daging sapi ke wilayah Jawa Barat dihitung dengan satuan ekor/ton.

5. QXs/ds adalah pengeluaran sapi atau daging sapi keluar wilayah Jawa Barat dihitung dengan satuan ekor/ton.

6. QRPHs adalah sejumlah sapi yang dipotong di Rumah Potong Hewan (RPH) di Jawa Barat yang dihitung dengan satuan ekor.

7. QDTds adalah total kebutuhan sapi atau daging sapi di Jawa Barat.

8. Cds adalah konsumsi daging sapi yang dihitung dari konsumsi daging sapi rata-rata per kapita per tahun dari masyarakat Jawa Barat dikali dengan jumlah penduduk di tahun bersangkutan yang dihitung dengan satuan ton.

9. Cdskap adalah konsumsi daging sapi rata-rata per kapita per tahun yang dihitung dengan $\mathrm{kg}$.

10. JPP adalah jumlah penduduk Jawa Barat pada tahun bersangkutan dihitung dengan satuan orang.

\section{Metode Analisis}

Metode analisis yang digunakan dalam penelitian ini adalah analisis matematika supply demand yang ditujukkan untuk mengukur neraca keseimbangan antara pasokan dan kebutuhan sapi dan daging sapi. Ada dua variabel yang diukur yaitu:

\section{a. Variabel Pasokan}

Variabel pasokan merupakan penjumlahan dari produksi, stok produksi, jumlah barang diimpor, dan keluarnya barang (Ilham, 2001; Kariasa, 2002). Jadi, total pasokan sapi/daging sapi (QTs/ds) adalah total produksi sapi/daging sapi ditambah jumlah sapi/daging sapi yang masuk dapat dirumuskan sebagai berikut:

- Total Pasokan Sapi dengan rumus sebagai berikut:

$$
\text { QSTs = QPs + QMs }
$$


$\mathrm{STs}=\mathrm{QPs}+\mathrm{QMs}-\mathrm{QXs}-\mathrm{QRPHs}$

- Total Pasokan Daging Sapi dengan rumus sebagai berikut:

QSTds $=$ QPds+ QMds

STds $=$ QPds + QMds - QXds

\section{b. Variabel Konsumsi}

Kebutuhan sapi dan daging sapi dapat diterjemahkan sebagai sejumlah daging sapi yang dikonsumsi dengan sejumlah daging sapi yang diekspor atau ke luar wilayah Jawa Barat (Andi, 2001). Persamaannya dapat dituliskan sebagai berikut:
- Total Kebutuhan Daging Sapi dengan rumus sebagai berikut:

QDTds $=$ Cds + QXds

Cds $=$ Cdskap x JPP

\section{HASIL DAN PEMBAHASAN}

\section{Pasokan Sapi dan Daging Sapi}

Pasokan sapi berasal dari populasi yang ada, pemasukan sapi, sapi yang keluar, dan sapi yang dipotong di RPH, dan stok sapi (Tabel 1).

Tabel 1. Pasokan Sapi dan Daging Sapi di Jawa Barat Tahun 2011-2015

\begin{tabular}{lrrrrr}
\hline Pasokan Sapi dan Daging Sapi & $\mathbf{2 0 1 1}$ & $\mathbf{2 0 1 2}$ & $\mathbf{2 0 1 3}$ & $\mathbf{2 0 1 4}$ & $\mathbf{2 0 1 5}$ \\
\hline Sapi (ekor) (QSTs) & & & & & \\
- QPs & 422.989 & 429.637 & 382.949 & 419.077 & 425.826 \\
- QMs & 367.440 & 390.587 & 288.372 & 317.518 & 219.226 \\
- QXs & 71.548 & 123.976 & 70.455 & 79.374 & 74.783 \\
- QRPHs & 295.489 & 259.808 & 249.035 & 234.818 & 275.751 \\
- STs & 423.392 & 436.440 & 351.831 & 422.403 & 294.518 \\
\hline Produksi Daging (ton) (QSTds) & & & & & \\
- QPds & 22.162 & 19.486 & 18.678 & 17.611 & 20.681 \\
- QMds & 56,314 & 54,826 & 53,204 & 49,462 & 54,797 \\
- QXds & tad & tad & tad & tad & tad \\
- STds & tad & tad & tad & tad & tad \\
\hline Keterad
\end{tabular}

Keterangan: Data diolah dari Dinas Peternakan Jawa Barat dan Ditjen Peternakan dan Kesehatan Hewan (2016)

Berdasarkan Tabel 1 dapat dilihat bahwa populasi sapi dari tahun 20112015 terjadi fluktuatif. Hal ini sangat tergantung dari pemasukan sapi dari luar wilayah Jawa Barat. Pasokan sapi dari luar Jawa Barat dari tahun 2011-2015 cenderung turun. Salah satu faktor penyebabnya adalah harga jual sapi yang relatif tinggi. Di samping itu, terdapat sapi-sapi yang keluar dari wilayah Jawa Barat yang besarnya relatif sama setiap tahunnya. Hasil populasi, pemasukan, pengeluaran, dan pemotongan sapi, maka dapat dihitung stok sapi tiap tahunnya. 
Hasilnya menunjukkan jumlah stok sapi dari tahun ke tahun mengalami penurunan.

Pasokan daging sapi pada dasarnya berasal dari hasil pemotongan sapi. Komponen pasokan daging sapi adalah produksi daging sapi hasil pemotongan di RPH/TPH, pemasukan daging sapi, stok, dan pengeluaran daging sapi. Secara tidak langsung, analisis pasokan daging sapi diturunkan dari pasokan sapi, seperti terlihat pada Tabel 1. Berdasarkan tabel tersebut dapat dilihat bahwa jumlah sapi di Jawa Barat mengalami penurunan yang cukup tajam di akhir tahun 2015 dilihat dari sisi stok sapi. Adapun hasil produksi daging diperoleh dari hasil pemotongan sapi di RPH/TPH di Jawa Barat.

Sapi-sapi yang dipotong di RPH/TPH terdiri atas sapi lokal dan sapi hasil penggemukan yang berasal dari sapi impor. Adapun hasil pemotongan sapi yang menghasilkan produksi berupa daging sapi (Tabel 1). Akan tetapi, jika dibandingkan dengan pemasukan daging sapi di Jawa Barat, maka daging sapi yang masuk lebih banyak dibandingkan dengan daging sapi hasil sembelihan di wilayah Jawa Barat. Hal ini menunjukkan bahwa Jawa Barat masih membutuhkan pasokan daging dari luar wilayah Jawa Barat.Salah satu faktor yang menyebabkan penawaran daging sapi meningkat karena dipengaruhi oleh harga sapi (Munte et al, 2014). Sangat disayangkan bahwa tidak adanya data jumlah daging sapi yang keluar Jawa Barat menyebabkan stok daging kesulitan untuk dihitung.

\section{Kebutuhan Daging Sapi}

Kebutuhan sapi dihitung dari jumlah konsumsi sapi dengan sejumlah daging sapi yang keluar wilayah Jawa Barat. Konsumsi daging sapi dihitung dari hasil perkalian antara kebutuhan standar daging sapi dikalikan dengan jumlah penduduk Jawa Barat dari tahun 2011-2015. Hasil perhitungan menunjukkan bahwa kebutuhan untuk konsumsi daging sapi di Jawa Barat dari tahun ke tahun terus meningkat (Gambar 1). Hal ini sejalan dengan terjadinya peningkatan jumlah penduduk dari tahun ke tahun. Adapun potensi daging sapi yang keluar Jawa Barat didekati dengan menghitung jumlah sapi yang keluar wilayah Jawa Barat. Dengan demikian, total kebutuhan daging sapi di Jawa Barat rata-rata sebesar 86 ribu ton per tahun atau setara dengan 710 ribu ekor jika berat rata-rata sapi sebesar 400 kg/ekor.

Berdasarkan hasil penelitian lainnya, harga daging sapi tidak 
berpengaruh pada permintaan daging sapi di Kota Surabaya (Rusdi dan Suparta, 2016). Artinya, permintaan daging sapi dapat dikatakan inelastis karena harga tidak mempengaruhi permintaannya. Berbeda pendapat dengan peneliti yang lainnya di mana harga daging sapi sangat berpengaruh pada permintaan daging sapi (Ilham, 2001; Priyanti et al, 1997). Oleh karena itu, harga daging sapi memiliki pengaruh yang berbeda antar wilayah di Indonesia.

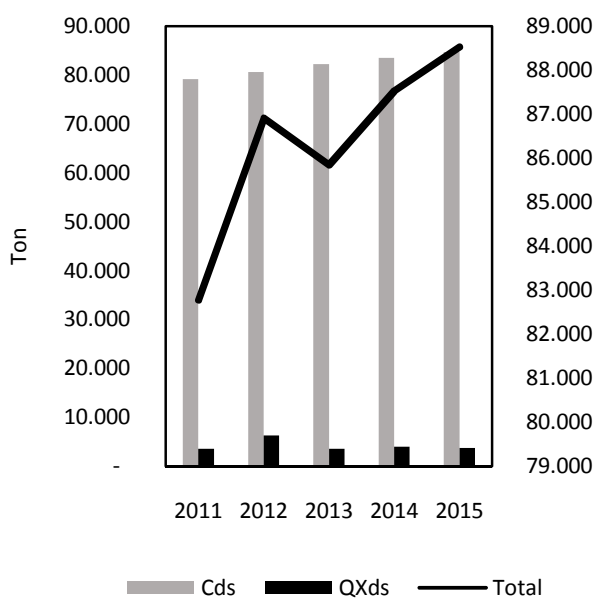

\section{Gambar 1. Kebutuhan Daging Sapi di Jawa Barat dari Tahun 2011-2015}

\section{Neraca Keseimbangan Pasokan dan}

\section{Kebutuhan Daging Sapi}

Pada uraian sebelumnya telah dijelaskan bahwa pasokan daging sapi didekati dari komponen pasokan sapi hidup. Sedangkan Kebutuhan daging sapi dilihat dari konsumsi daging dan potensi daging sapi yang keluar wilayah Jawa Barat. Berdasarkan data pasokan dan kebutuhan daging sapi tersebut, maka dapat dihitung neraca pasokan dan kebutuhan daging sapi yang dapat dilihat pada Gambar 2.

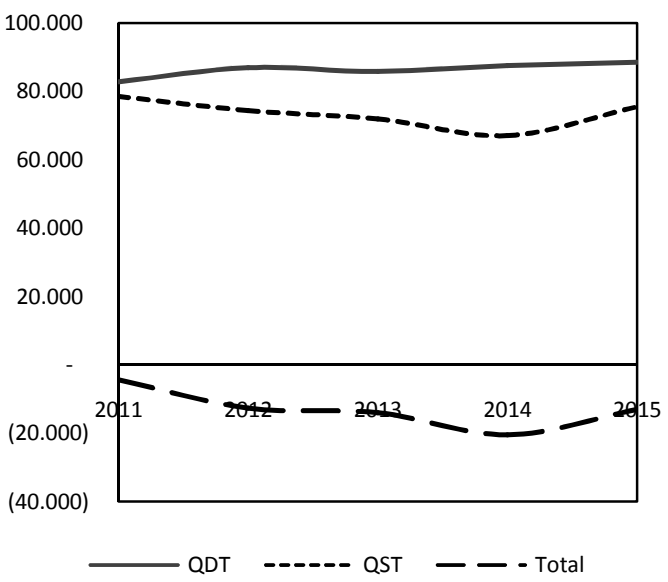

Gambar 2. Neraca Pasokan dan Kebutuhan Daging Sapi di Jawa Barat Tahun 2011-2015

Atas dasar Gambar 2 dapat diterangkan bahwa masih terjadi gap atau kekurangan pasokan daging sapi untuk wilayah Jawa Barat. Hal ini semakin memperjelas bahwa wilayah Jawa Barat merupakan wilayah konsumsi daging sapi. Di samping itu, selain wilayah konsumsi daging sapi, Jawa Barat juga mampu mengeluarkan sapi keluar wilayah Jawa Barat. Hal ini dapat dikatakan potensi daging produksi Jawa Barat mengalir ke luar wilayah provinsi ini. 


\section{PENUTUP}

Kesimpulan yang dapat diambil dari uraian di atas adalah sebagai berikut:

1. Pasokan daging sapi di Jawa Barat berasal dari daging sapi lokal dan sapi impor dari luar wilayah Jawa Barat yang besarnya $70 \%$ dibandingkan daging sapi lokal

2. Kebutuhan daging sapi rata-rata sebesar 86 ribu ton pertahun atau setara dengan jumlah sapi sebanyak 710 ribu ekor jika rata-rata berat hidup sebesar 400 kg/ekor. Adapun potensi daging sapi yang keluar dihitung dari jumlah sapi yang keluar wilayah Jawa Barat.

3. Neraca Pasokan dan Kebutuhan daging sapi di Jawa Barat adalah minus sehingga hal ini bisa jadi penyebab belum turunnya harga daging sapi walaupun sudah ada bantuan subsidi daging sapi dari Pemerintah Pusat.

\section{DAFTAR PUSTAKA}

Andi, S.C. 2001. Analisis Penawaran dan Permintaan Beras di Propinsi Lampung. Tesis Magister Sain. Program Pascasarjana, Institut Pertanian Bogor. Bogor.

Daniel, M., 2002. Pengantar Ekonomi Pertanian. Jakarta: Bumi Aksara.

Dinas Peternakan Provinsi Jawa Barat. 2016. Statistik Peternakan Jawa Barat Tahun 2016. Dinas
Peternakan Provinsi Jawa Barat. Bandung.

Direktorat Jenderal Peternakan dan Kesehatan Hewan. 2016. Statistik Peternakan Nasional Tahun 2016. Direktorat Jenderal Peternakan dan Kesehatan Hewan, Kementerian Pertanian. Jakarta.

Firdaus, A.,T. Susilawati, M. Nasich, dan Kuswati. 2012. Pertambahan Bobot Badan Harian Sapi Brahman Cross Pada Bobot Badan dan Frame Sizey ang Berbeda. Jurnal Ternak Tropika, 13(1): 48-62.

Hutauruk, J. 1996. Analisis Dampak Kebijakan Harga Dasar Padi dan Subsidi Pupuk terhadap Permintaan dan Penawaran Beras di Indonesia. Tesis Magister Sains. Program Pascasarjana, Institut Pertanian Bogor. Bogor.

Ilham, N. 2001. Analisis Permintaan dan Penawaran Daging Sapi di Indonesia. Seminar Nasional Teknologi Peternakan dan Veteriner. Pusat Penelitian dan Pengembangan Peternakan, Ditjen Peternakan, Kementerian Pertanian. Jakarta. Hal. 385-403.

Kariasa, K. 2002. Analisis Penawaran dan Permintaan Daging Sapi di Indonesia Sebelum dan Saat Krisis Ekonomi: Suatu Analisis Proyeksi Swasembada Daging Sapi 2005. Laporan Teknis Pusat Penelitian Sosial Ekonomi Pertanian, Badan Penelitian dan Pengembangan Pertanian, Kementerian Pertanian. Jakarta.

Koutsoyannis, A. 1982. Modern Microekonomics. Second Edition. London: The Mac Milan Press Ltd. Latifah, I.N., M. Paturochman, dan A. Firman. 2016. Perbandingan Usaha Pembibitan Sapi Peranakan Ongole dengan Sapi Persilangan di Desa Bunihayu Kecamatan Jalancagak 
Kabupaten Subang. Student eJournal, 3(5): 1-14.

Munte, O., S. N. Lubis, dan L. Fauzia. 2014. Analisis Faktor-faktor yang Mempengaruhi Penawaran Daging Sapi di Sumatera Utara. Journal on Social Economic of Agriculture and Agribusiness, 3(9): 21-30.

Nindi, D.W. 2013. Perlakuan Akuntansi Atas PPh Pasal 21 pada PT. Artha Prima Finance Kotamobagu. Jurnal Ekonomi, Manajemen, Bisnis, dan Akutansi (EMBA), 1(3): 558-566.
Rusdi, M.D., dan M. Suparta. 2016. Analisa Faktor-faktor yang Mempengaruhi Permintaan Daging Sapi di Kota Surabaya. Jurnal Ekonomi dan Bisnis, 1(2): 283-300.

Sukirno, S. 2013. Mikroekonomi Teori Pengantar. Edisi Ketiga. Jakarta: PT Raja Grafindo Persada.

Syafrizal. 2011. Keragaman Genetik Sapi Persilangan Simmental di Sumatera Barat. Jurnal Embrio, 4(1): 48-58. 